\title{
Algunas reflexiones sobre política económica, 2012
}

\author{
Marlilyn WARING \\ Auckland University of Technology \\ Marilyn.Waring@aut.ac.nz
}

Recibido: 03.12.2011

Aceptado: 05.01.2012

\section{RESUMEN}

Este artículo se centra en la importancia de la preservación del medio ambiente y critica el Informe de Stern, reconociendo los límites de la economía desde una perspectiva ética. No obstante, no es suficiente puesto que implica una mayor manipulación del mercado y el triunfo de los principios económicos sobre la defensa del medioambiente. Por el contrario, Elnor Ostrom, premio Nobel de economía ha demostrado que la cooperación es fundamental para la gestión de los recursos "comunales". Igualmente, los melanesios de Vanuatu han desarrollado prácticas de supervivencia increíbles durante centurias. En el presente, se puede decir que padecen crisis, pero no la crisis económica actual como el resto del mundo desde el año 2008.

Palabras clave: Contabilidad medioambiental, contaminación, cooperación, economía indígena, economía feminista.

\section{Some reflections on political economy, new year 2012}

\begin{abstract}
This article focuses on the preservation of environment considering the importance of the Stern's report recognizing many of the standard shortcomings of economics and focusing from an ethical perspective. Even though this perspective is not enough as it implies more market manipulation and the triumph of economic ideology over environmental principle. On the contrary, the Economy Nobel prize Elinor Ostrom has demonstrated that cooperation can provide for the sustainable management of the resources of the 'commons'. It can be said, that the Melanesian people of Vanuatu have developed extraordinary survival practices over centuries. Their lives have crises, but not the 'economic' crisis of 2008 as the west would understand it. .
\end{abstract}

Key words: Environmental accounts, pollution, cooperation, indigenous economy, feminist economics.

As we begin 2012, the focus of mainstream economic commentary continues to be on the financial crisis of 2008, and it's conversion to a public debt crisis. Many women's economies are always dealing with crises: examples include corrupt and incompetent political elites, erratic rainfall, food crises, global warming changes, traumatic events, whether tsunami, cyclones or floods, or endemic violence, whether assault, rape, or in war zones.

I am particularly aware of this in my neighbourhood, of Asia and the Pacific, where $60 \%$ of the world's population live. The regions have around 30 per cent of 
the global land mass and one billion of the world's poor. The vulnerability to natural disaster and conflict is significant. During 1975-2005 the region had 89 per cent of the people affected by disasters worldwide, 61 per cent of total fatalities and 47 per cent of total economic damage. Gender differences in deaths from natural disasters indicated that women and children are more vulnerable than men.

I have been thinking about how important it is for feminist political economists to be working in the field of environmental economics, and in particular critically watching the efforts to construct an environmental accounting system, because of the key issues for both women and the environment in the procedures and processes being established.

I had hoped that the implications of the Sterne Report on climate change might have had consequences for the economic centre piece of cost benefit analyses in all contexts. The Sterne Report ${ }^{1}$ rewrote the cost benefit analysis approach, adding in the externalities excluded in the neo classical approach. Sterne compared costs in reduced GDP or preventing climate change, against how much climate change would reduce the future growth of GDP. Although his approach to discounting and uncertainty are contested, Sterne's finding that 'using mainstream economics to analyse climate change stretched the discipline to its limits' is not seriously contested. He wrote that climate change presents a unique challenge for economics: it is the greatest and widest market failure ever seen.

Stern recognised many of the standard shortcomings of economics, and the report called for ethical perspectives 'focusing on welfare, equity and justice, freedom and rights'. It's not quite what I'd expect from a former Chief Economist of the World Bank, but it should never be too late for epiphanies.

However, the solution to Stern's 'failure of economics' is - predictably - yet more market manipulation. Carbon trading represents the triumph of economic ideology over environmental principle: carbon trading schemes privatise the public goods atmosphere, they normalise the 'right to pollute', and that there is a nominated 'share' of pollution which can be sold on if not used!, Carbon trading is based on an assumption that there are 'under - polluting' states and places. It does little to halt the over pollution activities of rich countries and companies. European heavy industries are currently the largest buyers of UN carbon credits, which they use to top up their own quotas.

Carbon trading has also been taken up in policy circles as a substitute for aid to poor countries: if poor countries can make money by selling their under- pollution credits, then foreign development assistance can be cut. Some countries see the new

\footnotetext{
1 Stern Review on the Economics of Climate Change

http://webarchive.nationalarchives.gov.uk/+/http:/www.hm-treasury.gov.uk/sternreview_index.htm
} 
market as a serendipitous windfall, far more likely to be sold several times over, and to end up in off shore tax havens, than in investment in basic needs. And stand by for bogus credits that create vast profits for certain groups.

The same CBA issue arose in the UN Biodiversity Report ${ }^{2}$, where the author, economist Pavan Sukhdev, referred to the damage currently being inflicted as " $a$ landscape of market failures". 3

If the natural world's goods and services are not valued and factored into the global environment, the environment will become too fragile and less resilient. The report suggested that the value of saving "natural goods and services", such as pollution, medicines, fertile soils, clean air and water, will be even higher - between $10-100$ times the cost of saving the species and habitats which provide them. The report details subsidies worth more than $\$ 1$ trillion a year for industries like agriculture, fisheries, energy and transport reform. It is always important to note that the bastions of free trade, the EU, US, Canada, and Japan, are those that still have in place the most protectionist measures. The report proposed fines and taxes to limit over exploitation, and called on businesses and governments to publish accounts for their use of natural and human capital alongside their financial results.

This is all happening in the context of the Integrated Environmental and Economic Accounting 2003 framework (SEEA 2003). This was developed as a satellite system to the System of National Accounts. The framework is to 'measure the contribution of the environment to the economy, and the impact of the economy on the environment'. It provides indicators and 'descriptive statistics' for monitoring, and as a data base etc.

The SEEA has an accounting framework with four categories.

The first set of flow accounts provide industry level information about the generation of pollutants and solid waste in production. The focus is pollution, energy and materials as inputs and externalities in the production process and output.

The second set of accounts identifies expenditure incurred by industry, government and households to protect the environment or to manage natural resources.

Natural resource asset accounts record stocks and changes of stocks of natural resources such as land, fish, forest, water and minerals.

\footnotetext{
2 http://www.cbd.int/doc/publications/gbo/gbo3-final-en.pdf

3 Guardian Weekly 28,05.10 Vol 182 No 24 ,p 5
} 
Adjustments concerning defensive expenditures, calculation of depletion and degradation costs of macroeconomic aggregates and advantages and disadvantages of these. ${ }^{4}$

It is very interesting to see what progress has been made in key issues in this development. ${ }^{5}$

Issue 18 is the valuation of water and the accounts 'recognise water is an economic good.' The issue of water valuation currently has the experts stumped. (Go water I say!). Fortunately, although the end result of the SEEA is to express environmental accounts as an abstracted monetary measure, -a temptation that is a dreadful policy trap - to reach this abstraction, a physical measure of a natural resource has to be made. Feminist intervention says: thanks for the physical data- and forget the abstractions to an accounting framework. In this it is similar to time use surveys. Thanks for the data, we can use that brilliantly for strategy, we don't need a market valuation. That is useful to demonstrate comparative abstractions with elements of the market economy, but this data is not useful when translated to market abstractions. Necessary decisions are isolated in an economic paradigm which cannot be generalised statistically. The world is not full of market trade offs, and most external characteristics of 'value' for both the environment, and unpaid work, which do not need abstraction to a market equivalent for policy judgments to be exercised.

Governance of the environment is a key consideration for changes to the mainstream. The award of the Nobel Prize in Economics in 2009 to Elinor Ostrom was a good opportunity for feminist economists to look at developments in economics, which are not a central part of the mainstream paradigm. Ostrom's work is about cooperation, not competition, about communities self-organizing to solve common problems, in particular in the governance of the commons. ${ }^{6}$ Over many years and in many countries, Ostrom has demonstrated how something other than self- interest can provide for the sustainable management of the resources of the 'commons', such as water, forestry, lands, the foreshore and seabed, and fisheries. More recent work has demonstrated that women's participation in decision making at the user group level and in forest communities enhances regeneration, reduces illegal harvesting with improved monitoring, increases the group's capacity to manage and resolve conflicts, which then increases compliance and respect for harvesting and use rules. ${ }^{7}$ The wisdom of local people to resolve their conflicts consistently works better than

\footnotetext{
4 http://unstats.un.org.unsd/envAccounting/seea.asp

5 http://un.org/unsd/envaccounting/

6 Elinor Ostrom , A General Framework for Analyzing Sustainability of Social-Ecological Systems, Science 24 July 2009: Vol. 325 no. 5939 pp. 419-422

7 SUN Y, MWANGI E, AND MEINZEN-DICK R: 'Gender, institutions and sustainability in the context of forest decentralisation reforms in Latin America and East Africa, CIFOR info, No 25, August 2010
} 
the expert from afar. Frequently the Governance of the Commons solution is an indigenous one where all externalities are considered.

There is now a healthy indigenous initiative in response to the market economics paradigm of value of resources and community exchanges, and the governance of the commons, being undertaken in Melanesia, led by a pilot in the field (in 2011) with Vanuatu's Census. ${ }^{8}$ Cabinet Minister Ralph Regenvanu has promoted this initiative. The questions are collecting a picture of what is called the 'indigenous' economy. This is so titled to escape any paradigm current mainstream economic terms such as 'subsistence' or 'informal' might impose as a colonizer of what is to be demonstrated here. Now the Melanesian people of Vanuatu and the Pacific know about living with trauma, but these are usually climatic and geological events. These communities have developed extraordinary survival practices over centuries. Their lives have crises, but not the 'economic' crisis of 2008 as the west would understand it.

Regenvanu argues that the overwhelming numbers of Melanesia's populations were not impacted by the 2008 recession as they were sustained by and continued to work within the 'indigenous' economy, where the commons provides. Questions asked, for example, 'do you have access to common forests and lands for housing materials, for the building of canoes? Do you have access to common grounds to grow food? Do you help people in your community to build their houses? Do others in the community assist you in building your home?

This approach shares a lot with Canadian research on 'provisioning work', which imagines in new ways the dimensions of women's work within households, organisations and communities. ${ }^{9}$ Sustained work across six research sites for 4 years has been carried out, with considerable insights about environmental protection, governance and community, in a myriad of ways not valued by market exchanges, but by providing the necessities of life in a range of activities that are never finished.

While we find we are still having to battle the pathologies of old fashioned accounting frameworks, I get plenty of energy from these alternative evidenced alternatives to keep me going for another year.

\footnotetext{
8 See also RATUVA, S. (2010). Back to basics: Toward integrated social protection for vulnerable groups in Vanuatu. Pacific Economic Bulletin, 25(3), 40-63. Retrieved from http://peb.anu.edu.au/pdf/PEB25_3_Ratuva_BB.pdf

9 NEYSMITH S.M, REITSMA - STREET, M., BAKER COLLINS S, and PORTER E: Beyond Caring Labour to Provisioning Work, University of Toronto Press, 2012 ( in production).
} 


\section{REFERENCES}

NEYSMITH S.M., REITSMA - STREET, M., BAKER COLLINS, S. \& PORTER. E.: Beyond Caring Labour to Provisioning Work, University of Toronto Press, 2012 (in production).

OSTROM, Elinor (2009),"A General Framework for Analyzing Sustainability of Social-Ecological Systems”, Science 24 July 2009: Vol. 325 no. 5939 pp. 419-422

RATUVA, S. (2010). "Back to basics: Toward integrated social protection for vulnerable groups in Vanuatu”. Pacific Economic Bulletin, 25(3), 40-63. Retrieved from http://peb.anu.edu.au/pdf/PEB25_3_Ratuva_BB.pdf

Stern Review on the Economics of Climate Change http://webarchive.nationalarchives.gov.uk/+/http:/www.hm-treasury.gov.uk/sternreview_index.htm

SUN, Y., MWANGI, E. and MEINZEN-DICK, R (2010) Gender, institutions and sustainability in the context of forest decentralisation reforms in Latin America and East Africa, CIFOR info, No 25, August 2010. 